\title{
THE EDUCATION RELATIONSHIP DEVELOPMENT BETWEEN CHINA AND INDONESIA AS ASEAN MEMBER
}

\author{
Adi Maulana \\ Vocational and Technical Education, Nanjing Normal University \\ Nanjing Jiangsu Province, China \\ amp_aflah@yahoo.com
}

\begin{abstract}
China and ASEAN have long history on their relationship. One of ASEAN countries, Indonesia, along with China are two big countries in Asia with similar national interests and objectives in partnership, which are peace and prosperity of G2O, APEC, $10+1$, and 10+3, in which Indonesia is an active participant. One of the cooperation between China and ASEAN is through education. Indonesia may promote student exchange as well as proposing the idea of students exchange in various forums such as ASEAN-China freetrade, culture, tourism, education and many others. However, the data shown that the proportion of ASEAN students in China do not reflect the proportion of population of each ASEAN countries. Indonesia, the largest country by population, only sends the second biggest number of students to China behind Thailand, which puts the most students in China Education. This paper discusses the ups and downs of Indonesia-China relationship in education. SWOT analysis is used to see Indonesia-China relationship in the perspective of ASEAN. It can be concluded that cooperation among countries is inevitable measure facing the more challenging world. However the rough past has created mistrust and prejudice on both sides. But the need to collaborate has shown to be beneficial in promoting education cooperation.
\end{abstract}

Keyword: ASEAN, China, students exchange, relationship and SWOT analysis.

\section{INTRODUCTION}

The Association of Southeast Asian Nations, or ASEAN, was established on 8 August 1967 in Bangkok, Thailand, with the signing of the ASEAN Declaration (Bangkok Declaration) by the Founding Fathers of ASEAN, namely Indonesia, Malaysia, Philippines, Singapore and Thailand (www.asean.org, 2017). Indonesia is one of leading ASEAN members in population, economy and territory.

As countries living in near proximity, ASEAN members share borders with each other. Indonesia has some border geographically with other countries; for example the province of Nusa Tenggara Timur borders with Timor Leste, Kalimantan Island with Malaysia, and Papua with Papua New Guinea. Some of the members of ASEAN have geographical borders with China. 
But, Indonesia as the largest country does not directly border with China. Nevertheles, Indonesia parcipate actively in in the economic cooperation of ACFTA (ASEAN-China Free Trade Area) which will take effect in 2020 with the agreement to beginning of 2015. Indonesia also plays a part in various China and ASEAN collaboration not only in trade but almost every sector for example politics, education, culture, tourism, science, technology, transportation, agricultural, health, and information (http://asean.org/asean/aboutasean/overview).

China is deemed a superpower in the Asia-Pacific region. It is a country that has a huge population of almost of 1.4 billion emerging as a wellrespected economy power (http://www.worldpopulationstatistics.com). It has started to spread its influence in ASEAN, including Indonesia. China and ASEAN are good neighbors, friends and partners enjoying geographical proximity and cultural affinity. Over the past 25 years, with joint efforts of of two sides, ASEAN-China relations have made impressive achievements. The two sides have deepened their political mutual trust, developed increasingly close economic, trade ties, achieved fruitful result in people-to-people, cultural exchanges and over 190,000 exchange students between the two sides.

\section{ASEAN and China in Education}

In particular, China-ASEAN cooperation in education, China and ASEAN have carried out various forms of cooperation in the field of education, achieving fruitful results in following events:

1. ASEAN-China Education Cooperation week

Co-hosted by the Chinese ministry of foreign affairs, ministry of education and Guizhou Provincial People's Government. ASEAN-China Education Cooperation week was launched in 2008.

2. ASEAN-China Educational Exchange Year

The year 2016 is the year of ASEAN-China Educational Exchange. Since the beginning of the year, China and ASEAN countries have organized over 200 educational exchange activities, which have further enhanced ASEAN-China educational cooperation and deepened their people-to-people and cultural exchange. 
Maulana, The Education Relationship Development between China and Indonesia ...

3. China-ASEAN Student Exchange Program

China stated at the ASEAN-China Education ministers Roundtable in 2010 that the two sides would implement the "Double 100,000 Plan" to bring the number of Chinese and ASEAN students in each other's Universities to 100,000 respectively by 2020. From 2010 to 2015, the number of students from ten ASEAN countries studying in China increased from 49,580 to 71,101 , representing an average annual growth of $7.5 \%$. The goal of 100,000 students from ASEAN countries studying in China is expected to be realized by 2020. On the other hand, by the end of 2015. The accumulated number of Chinese students studying in ASEAN countries amounted to 124178.

4. ASEAN-China Education Training Mechanism

Since 2009, China has sent a total of 1,198 Chinese language teachers and 15,319 volunteers to ASEAN countries, and provided Confucius Institute scholarship to 6,210 people. By the end of 2015, China has opened 31 Confucius Classrooms in ASEAN countries, cultivating a total of over 250,000 Chinese language students (Ministry of foreign Affairs of the People's Republic of China ASEAN-China Centre, 2016).

The following table shows the numbers of students from ASEAN countries studying in China and those on scholarships in from 1991 to 2015.

Table 1. ASEAN Students and Scholarship in 1991-2015

\begin{tabular}{ccccccccc} 
& \multicolumn{2}{c}{1991} & \multicolumn{2}{c}{1997} & \multicolumn{2}{c}{2003} & \multicolumn{2}{c}{2015} \\
\cline { 2 - 9 } Country & $\begin{array}{c}\text { Num } \\
\text { ber } \\
\text { of } \\
\text { stude } \\
\text { nts }\end{array}$ & $\begin{array}{c}\text { School } \\
\text { arship }\end{array}$ & $\begin{array}{c}\text { Numbe } \\
\text { r of } \\
\text { student } \\
\text { s }\end{array}$ & $\begin{array}{c}\text { School } \\
\text { arship }\end{array}$ & $\begin{array}{c}\text { Number } \\
\text { of } \\
\text { students }\end{array}$ & $\begin{array}{c}\text { School } \\
\text { arship }\end{array}$ & $\begin{array}{c}\text { Number } \\
\text { of } \\
\text { students }\end{array}$ & $\begin{array}{c}\text { School } \\
\text { arship }\end{array}$ \\
\hline Brunei & 0 & 0 & 0 & 0 & 4 & 0 & 62 & 3 \\
\hline Cambodia & 5 & 5 & 82 & 2 & 139 & 50 & 1829 & 586 \\
\hline Indonesia & 5 & 0 & 921 & 1 & 2563 & 7 & 12694 & 521 \\
\hline Laos & 15 & 15 & 68 & 39 & 405 & 284 & 6918 & 1156 \\
\hline Malaysia & 11 & 0 & 502 & 0 & 841 & 26 & 6650 & 264 \\
\hline Myanmar & 5 & 5 & 6 & 0 & 232 & 25 & 4733 & 249 \\
\hline The & 39 & 9 & 232 & 0 & 602 & 8 & 3343 & 63 \\
\hline Philippines & 41 & 0 & 303 & 3 & 551 & 26 & 4865 & 104 \\
\hline Singapore & 60 & 7 & 367 & 4 & 1554 & 41 & 19976 & 1555 \\
\hline Thailand & 2 & 0 & 253 & 42 & 3487 & 196 & 10031 & 2146 \\
\hline Vietnam & 183 & 41 & 2734 & 91 & 10378 & 663 & 71101 & 6647 \\
\hline Total & & & & & Source: Ministry of Education, China
\end{tabular}


Table 2. Exchange students between China and ASEAN countries in 2015

\begin{tabular}{ccccc} 
No & Country & $\begin{array}{c}\text { Number of } \\
\text { students } \\
\text { studying in } \\
\text { China }\end{array}$ & $\begin{array}{c}\text { Number of } \\
\text { Chinese } \\
\text { students } \\
\text { received }\end{array}$ & $\begin{array}{c}\text { Total number } \\
\text { of exchange } \\
\text { students }\end{array}$ \\
\hline 1 & Singapore & 4,865 & 80,850 & 85,715 \\
\hline 2 & Thailand & 19,976 & 30,526 & 50,502 \\
\hline 3 & Malaysia & 6,650 & 10,775 & 17,425 \\
\hline 4 & Indonesia & 12,694 & $750^{*}$ & 13,444 \\
\hline 5 & Vietnam & 10,031 & 919 & 10,950 \\
\hline 6 & Laos & 6,918 & 325 & 7,243 \\
\hline 7 & Myanmar & 4,733 & 4 & 4,737 \\
\hline 8 & The Philippines & 3,343 & 6 & 3,349 \\
\hline 9 & Cambodia & 1,829 & 23 & 1,852 \\
\hline 10 & Brunei & 62 & 0 & 62 \\
\hline & Total & 71,101 & 124,178 & 195,279 \\
\hline
\end{tabular}

Source: Ministry of Education China; *The source is taken from the data of the Indonesian Embassy in China

\section{DISCUSSION}

Numbers of students from ASEAN countries studying in China and those of Scholarships in 1991 to 2015

Table 3 ASEAN students in China and the Scholarships

\begin{tabular}{|c|c|c|c|c|c|c|c|c|c|c|}
\hline \multirow[b]{2}{*}{ Country } & \multicolumn{2}{|c|}{1991} & \multicolumn{2}{|c|}{1997} & \multicolumn{2}{|c|}{2003} & \multicolumn{2}{|c|}{2015} & \multirow[b]{2}{*}{$\begin{array}{c}\text { Total } \\
\text { every } \\
\text { country }\end{array}$} & \multirow[b]{2}{*}{$\begin{array}{c}\text { Total } \\
\text { every } \\
\text { country } \\
\text { in } 2015\end{array}$} \\
\hline & $\begin{array}{c}\mathrm{Nu} \\
\text { mbe } \\
\text { r of } \\
\text { stud } \\
\text { ents }\end{array}$ & $\begin{array}{c}\text { Sc } \\
\text { ho } \\
\text { ol } \\
\text { ar } \\
\text { shi } \\
\text { p }\end{array}$ & $\begin{array}{l}\mathrm{Nu} \\
\text { mbe } \\
\mathrm{r} \text { of } \\
\text { stud } \\
\text { ents }\end{array}$ & $\begin{array}{l}\text { Sch } \\
\text { oola } \\
\text { rshi } \\
\text { p }\end{array}$ & $\begin{array}{c}\text { Numb } \\
\text { er of } \\
\text { stude } \\
\text { nts }\end{array}$ & $\begin{array}{l}\text { Sch } \\
\text { ool } \\
\text { arsh } \\
\text { ip }\end{array}$ & $\begin{array}{c}\text { Numb } \\
\text { er of } \\
\text { stude } \\
\text { nts }\end{array}$ & $\begin{array}{l}\text { Sch } \\
\text { ool } \\
\text { arsh } \\
\text { ip }\end{array}$ & & \\
\hline Brunei & 0 & 0 & 0 & 0 & 4 & 0 & 62 & 3 & 69 & 65 \\
\hline Cambodia & 5 & 5 & 82 & 2 & 139 & 50 & 1829 & 586 & 2698 & 2415 \\
\hline Indonesia & 5 & 0 & 921 & 1 & 2563 & 7 & 12694 & 521 & 16712 & 13215 \\
\hline Laos & 15 & 15 & 68 & 39 & 405 & 284 & 6918 & 1156 & 8900 & 8074 \\
\hline Malaysia & 11 & 0 & 502 & 0 & 841 & 26 & 6650 & 264 & 8294 & 6914 \\
\hline Myanmar & 5 & 5 & 6 & 0 & 232 & 25 & 4733 & 249 & 5255 & 4982 \\
\hline $\begin{array}{l}\text { The } \\
\text { Philippines }\end{array}$ & 39 & 9 & 232 & 0 & 602 & 8 & 3343 & 63 & 4296 & 3406 \\
\hline Singapore & 41 & 0 & 303 & 3 & 551 & 26 & 4865 & 104 & 5893 & 4969 \\
\hline Thailand & 60 & 7 & 367 & 4 & 1554 & 41 & 19976 & 1555 & 23564 & 21531 \\
\hline Vietnam & 2 & 0 & 253 & 42 & 3487 & 196 & 10031 & 2146 & 16157 & 12177 \\
\hline Total & 183 & 41 & 2734 & 91 & 10378 & 663 & 71101 & 6647 & 91838 & \\
\hline
\end{tabular}

Table 4 shows the numbers of students from ASEAN countries

studying in China in comparison to population of ASEAN country from largest to smallest. 
Maulana, The Education Relationship Development between China and Indonesia ...

Table 4. Students from ASEAN Countries in comparison to ASEAN country population

\begin{tabular}{clccc}
\hline No & Country & $\begin{array}{c}\text { Student } \\
\text { studying in } \\
\text { China }\end{array}$ & Population in million & $\begin{array}{c}\text { Percentage of ASEAN } \\
\text { population (\%) }\end{array}$ \\
\hline 1 & Thailand & 21531 & 66785 & 10.98 \\
\hline 2 & Indonesia & 13215 & 246864 & 40.58 \\
\hline 3 & Vietnam & 12177 & 88775 & 14.59 \\
\hline 4 & Laos & 8074 & 6646 & 1.09 \\
\hline 5 & Malaysia & 6914 & 29240 & 8.81 \\
\hline 6 & Myanmar & 4982 & 52797 & 0.67 \\
\hline 7 & Singapore & 4969 & 5312 & 15.9 \\
\hline 8 & The Philippines & 3406 & 96707 & 2.44 \\
\hline 9 & Cambodia & 2415 & 14865 & 0.07 \\
\hline 10 & Brunei & 65 & 0.412 & \\
\hline
\end{tabular}

The following chart show graphically the figure of ASEAN students studying in China with every country (Ghozali, 2013).

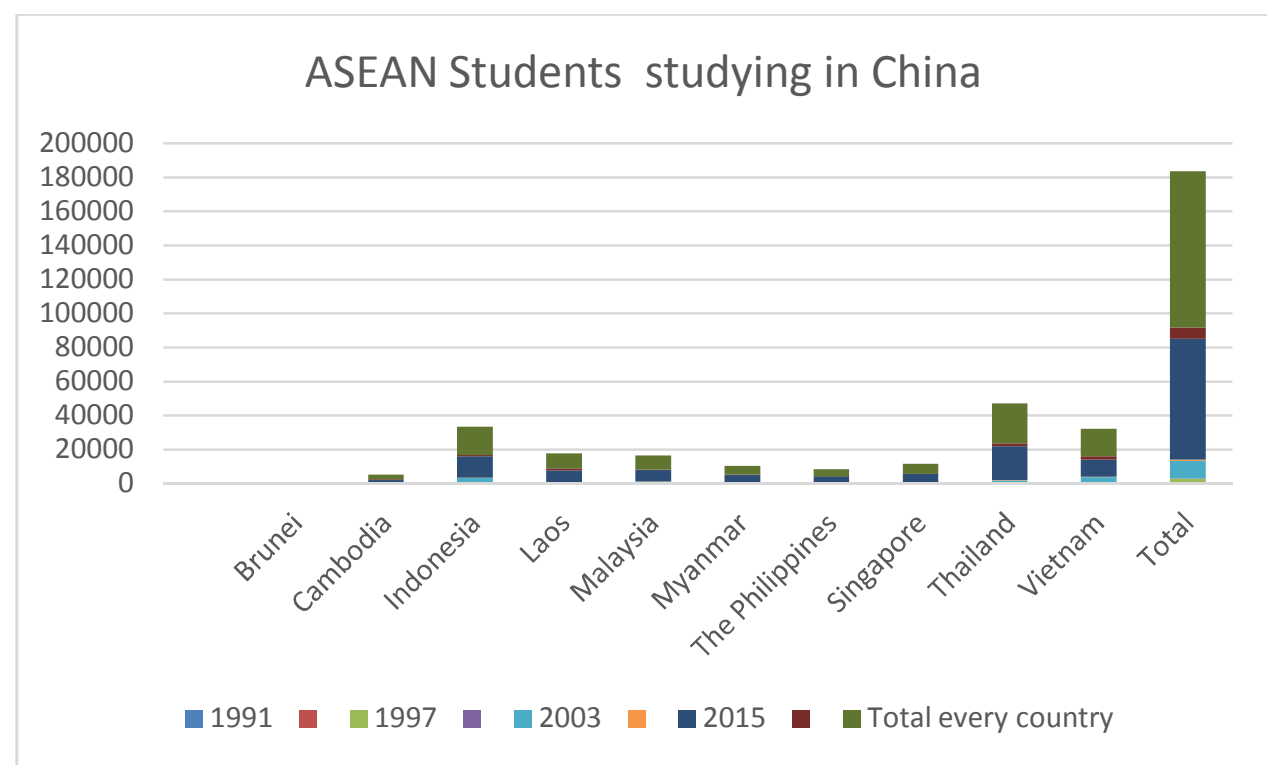

Figure 1. ASEAN Students studying in China

The chart arguably shows disproportion of ASEAN students in China which does not reflect the population proportion of ASEAN. China plans to have 100,000 ASEAN students from currently 71.101 in 2020 . So it still 28.899 more students to get to 100.000. Indonesia, which has the largest population, should have higher number of students, if proportion is to base on. 
Table 5. Number of ASEAN students in China

\begin{tabular}{ccccc}
\hline No & Percentage (\%) & $\begin{array}{c}\text { Population ASEAN in } \\
\text { million }\end{array}$ & Country & $\begin{array}{c}\text { Students from } \\
\text { ASEAN }\end{array}$ \\
\hline 1 & 40.58 & 246864 & Indonesia & 11727 \\
\hline 2 & 15.9 & 96707 & The Philippines & 4594 \\
\hline 3 & 14.59 & 88775 & Vietnam & 4216 \\
\hline 4 & 10.98 & 66785 & Thailand & 3173 \\
\hline 5 & 8.68 & 52797 & Myanmar & 2508 \\
\hline 6 & 4.81 & 29240 & Malaysia & 1390 \\
\hline 7 & 2.44 & 14865 & Cambodia & 705 \\
\hline 8 & 1.09 & 6646 & Laos & 315 \\
\hline 9 & 0.87 & 5312 & Singapore & 251 \\
\hline 10 & 0.07 & 0.412 & Brunei & 20 \\
\hline & & & & $\mathbf{2 8 , 8 9 9}$ \\
\hline
\end{tabular}

Table 5 shows how number of ASEAN students in China may look in relation to their population.

In following table, we can get the total figure of exchange students between China and ASEAN countries in 2015.

(Arranged in descending order of the number of exchange of students)

Table 6. Exchange Students in 2015

\begin{tabular}{|c|c|c|c|c|c|c|c|}
\hline No & $\begin{array}{l}\text { ASEAN } \\
\text { country }\end{array}$ & $\begin{array}{l}\text { Number } \\
\text { of } \\
\text { Chinese } \\
\text { students } \\
\text { studying } \\
\text { in } \\
\text { ASEAN }\end{array}$ & $\begin{array}{l}\text { Number } \\
\text { of } \\
\text { ASEAN } \\
\text { students } \\
\text { studying } \\
\text { in China }\end{array}$ & $\begin{array}{l}\text { Total } \\
\text { number } \\
\text { of } \\
\text { exchange } \\
\text { students }\end{array}$ & $\begin{array}{l}\text { Percentage } \\
\text { Chinese } \\
\text { students } \\
\text { studying in } \\
\text { ASEAN (\%) }\end{array}$ & $\begin{array}{l}\text { Percentage } \\
\text { Number of } \\
\text { ASEAN } \\
\text { students } \\
\text { studying in } \\
\text { China } \\
(\%)\end{array}$ & $\begin{array}{l}\text { Percentage } \\
\text { difference }\end{array}$ \\
\hline 1 & Singapore & 80,850 & 4,865 & 85,715 & 65.108 & 6.84 & 58.268 \\
\hline 2 & Thailand & 30,526 & 19,976 & 50,502 & 24.582 & 28.10 & -3.518 \\
\hline 3 & Malaysia & 10,775 & 6,650 & 17,425 & 8.677 & 9.35 & -0.673 \\
\hline 4 & Indonesia & 750 & 12,694 & 13,444 & 0.604 & 17.85 & -17.246 \\
\hline 5 & Vietnam & 919 & 10,031 & 10,950 & 0.740 & 14.11 & -13.37 \\
\hline 6 & Laos & 325 & 6,918 & 7,243 & 0.262 & 9.73 & -9.468 \\
\hline 7 & Myanmar & 4 & 4,733 & 4,737 & 0.003 & 6.66 & -6.657 \\
\hline 8 & $\begin{array}{l}\text { The } \\
\text { Philippines }\end{array}$ & 6 & 3,343 & 3,349 & 0.005 & 4.70 & -4.695 \\
\hline 9 & Cambodia & 23 & 1,829 & 1,852 & 0.019 & 2.57 & -2.551 \\
\hline 10 & Brunei & 0 & 62 & 62 & 0.000 & 0.09 & -0.09 \\
\hline & Total & 124,178 & 71,101 & 195,279 & & & \\
\hline
\end{tabular}

Source Ministry of Education China

Note: minus (-) is meaning that percentage number of students studying in China from ASEAN country more than percentage number of Chinese students studying in ASEAN countries.

From table 6, it is understood that the most significant number of Chinese studying in ASEAN country is at Singapore about $65.108 \%$ in contrast to the number of students from Singapore studying in China which is only $6.84 \%$. In 
Maulana, The Education Relationship Development between China and Indonesia ...

general except Singapore percentage number of Chinese students received in ASEAN country showing in minus value it is mean ASEAN students studying in China is more than Chinese students received in ASEAN country. In Indonesia, specifically, only $0.604 \%$ approximately 750 people studying.

Opportunity proportional exchange students

Improving equity at all levels and increasing participation in senior secondary education is vital for Indonesia. Currently less than one-third of Indonesian complete secondary education. Increasing this learning participation necessitates in increasing quality of life, work and further learning prospects of students (Heirsh and Sharif, 2013). This in turn means paying greater attention to the development of cognitive and interpersonal skills. It will also be necessary to allow students flexibility to enter, exit and re-enter education depending on their financial and social circumstances, and to create pathways between academic and vocational tracks.

Increasing Efficiency and Effectiveness

Indonesia devotes $20 \%$ of government expenditure to education. Capitalising on this investment implies increasing efficiency. This will require a more transparent and data driven basis for assigning resources, better tailoring of provision to local needs and circumstances, and stronger performance management (Schleicher, 2015).

Strength relationship between Indonesia and China in education

China and Indonesia are big countries in Asia sharing the same needs and goal in parthership for peace and prosperity. That is why they coordinate regional organizations like United Nations, G20, APEC, 10+1 (ASEAN with China) and 10+3 (ASEAN with China, Japan and Korea) (KBRI in China, 2015). The cooperation between China and ASEAN is on the basis that Southeast Asian countries are fully aware of the growing influence of China and this growing influence has undoubtedly created some security concern in the region among other concerns (Politics, Education, Economy, Health and other field) (Banlaoi, 2003). 


\section{EduLite}

Journal of English Education, Literature, and Culture

Volume 3, Number 1, February 2018

The invitation to Chine to be present on ASEAN Summit is one of media to perfect understanding between ASEAN and China. This will lead to the establishment of ASEAN-China center which will facilitate promotion and coorperation in trade, investment, tourism, education and culture, with active involvement of the private sector. It is also aimed at increasing people-topeople contacts, public awareness, mutual understanding, as well as active participation among the ASEAN and Chinese peoples through cultural and educational exchanges (ASEAN Summit 15th, 2009). So, eventually it will strengthen the relationship between ASEAN and China especially Indonesia.

Weakness of Indonesia to Prepare Competition

Looking back, the Indonesia-China relationship has been on rocky path since their independence. The years 50 s and 60 s saw close relationship between these two nations. It deteriotared in 70s. Then, they tried to mend it after 1978. It culminated by the establishment of ASEAN-China centre in Beijing. On October 2003, the leader of ASEAN and China signed a strategic partnership for peace and prosperity in Bali (He, 2015).

Until now, an unpleasant relationship between Indonesia-China in past still lingers in many Indonesian people. This makes some of them see China as a threat. Learning from other Asian countries, it may not be wise not to cooperate with other countries. Countries need to keep on cooperating and coordinating for development of human resources and involves it self in manpower planning and job placement and increasingly in the coordination of science and technology (Booth, 1999).

On the other hand, Indonesia policies have been especially astute at planning educational development in order to meet the demands of a fastchanging labour market. Indeed, in several cases, it is very clear that educational and skills bottlenecks have forced goverments into relying on expatriate labour. and in some cases the lack of skillful human resources retard economic growth. It is clear that the mistakes comitted by Southeast Asian goverments in the education sector have been less heinous than in many other countries (Booth, 1999). We understand that United Nations Educational, Scientific and Cultural Organization (UNESCO) confirms that 
Maulana, The Education Relationship Development between China and Indonesia ...

the substance of learning have four learning: Learning to know, learning to do, learning to be, and learning to live together. That is why the Government of Indonesia prefer course or training in Indonesia and emphasize on the important goal life long learning (Rubini, 2007), and to prepare of demand market in Asia Pacific region.

\section{Threat Relationship Between ASEAN and China}

The World Bank reported that in 1990 there were roughly 375 million people in China living in extreme poverty, on less than $\$ 1$ per day, but in 2015 only 16 million who still live on less than $\$ 1$ a day. This economic development of China is bigger than South Asia and countries in subSaharan Africa (Friedman, 2007). In addition to that, China's official defense budget has increased at an average of around 11 percent per year. it shows how hegemony in Asia region has been becoming a so-called "theater peer" of United States (Lee, 2005). China becomes more powerful with matching influence over every major sector-from energy excavation to selective sea control-the U.S.-led security template. As a matter of fact, China plays strategic key roles in the region, there are four other countries seen from this perspective, four key actors bear closer observation: Japan, South Korea, India and Indonesia (Friedman, 2007).

Indonesia is located in the same continent as China. Even though Indonesia has no direct borders with China, its influence is prevalence. Not only to Indonesia, but also ASEAN, for their proximity to China. Unfortunately, the United States seems not to favor that situation, so it allegedly commence South Sea of China dispute to disrupt the stability and China-ASEAN relationship.

One thing to take into consideration is the international language barrier (English, Mandarin, Arabic, French, Russian, and Spanish) (http://www.organisasi.org/1970/01/ international language barrierpbb.html) and further education in the framework of lifelong learning (Felix Rauner, European vocational education and training (Bremen, 2008). It is particularlychallenging for Indonesian since both countries do not share land border. Countries such as Vietnam, Laos and Myanmar have their advantage 
to get familiar with Chinese culture because they share land border with China. This can be positive competition for Indonesian and threat, because limitedness of China Scholarship.

Table 7. SWOT Analysis Relationship Between ASEAN and China

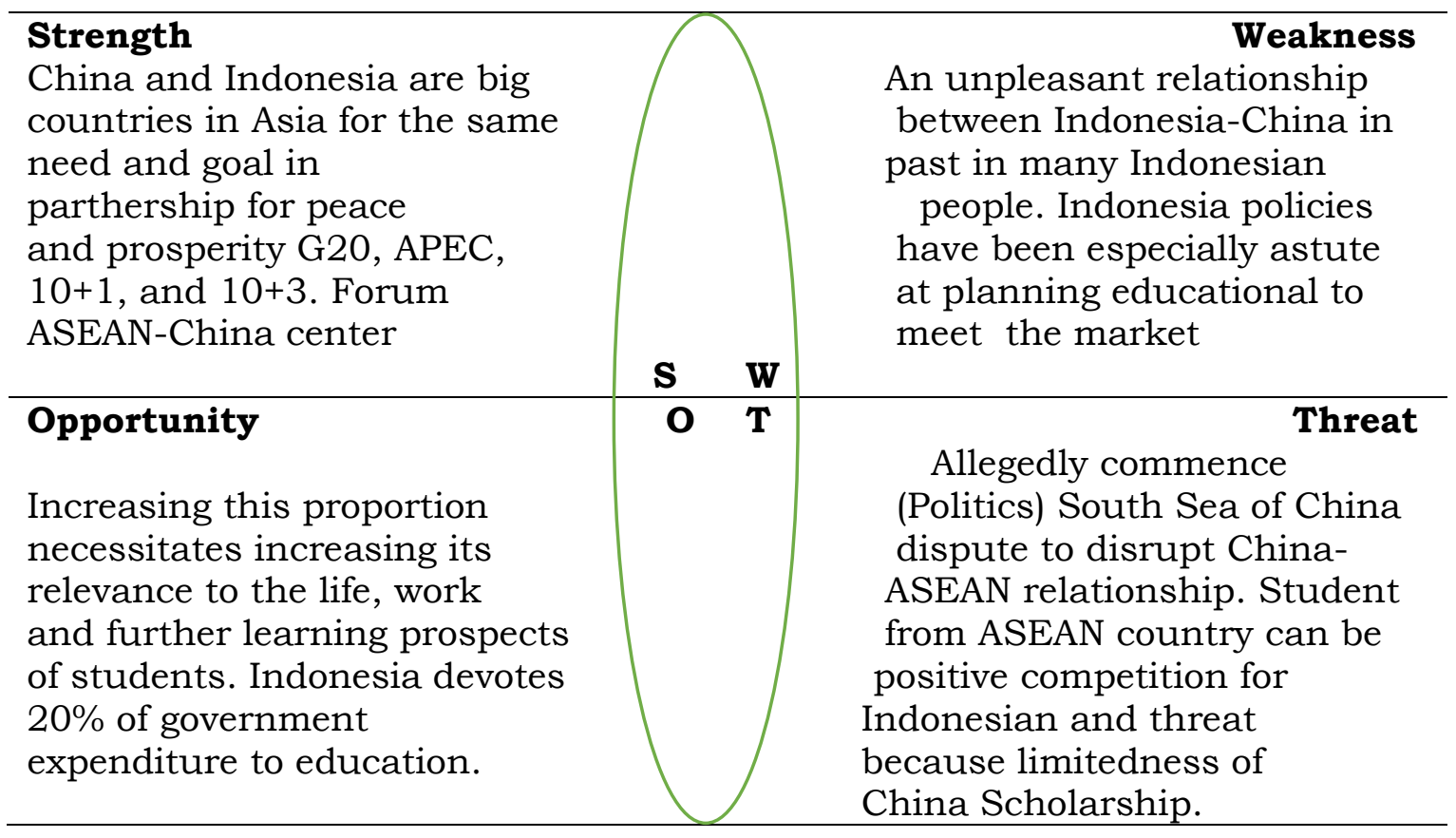

\section{CONCLUSION}

China and Indonesia are two big countries in Asia with similar national interests and objectives in partnership, peace and prosperity of G20, APEC, $10+1$, and 10+3, in which Indonesia is an active participant. In addition to that, Indonesia as the ASEAN leader must initiate better relationship among Asian nations. Indonesia may promote student exchange as well as idea exchange in various forums such as ASEAN-China free-trade, culture, tourism, education and many others.

Indonesian government may want to ensure that Indonesian people have learned from the past for positive future bilateral relationship and not as a dim shadow for a distrust. Indonesia should focus on preparing Indonesian people, especially their education, to face global market. Indonesians need to learn from other countries to win this competition. The number of Indonesian studying overseas must in relevance with the national need, work field and 
Maulana, The Education Relationship Development between China and Indonesia ...

the future of the overseas students. With $20 \%$ national budget on education, Indonesia could send more potential students especially from low income families to continue studying abroad.

The political situation in South Sea of China allegedly commence dispute to disrupt the stability and China-ASEAN relationship, Indonesian goverment should be peacemaker in that situation. Indonesian student should be prepared with good skill in international language to competition with students other country especially Association of Southeast Asian Nations (ASEAN).

\section{Acknowledgements}

For Prof. Gu Jian Jun, Ph.D Dean Faculty of education Nanjing Normal University, China and research supervisor to encouraging my work.

\section{REFERENCES}

ASEAN Summit 15th Thailand. (2009) MoU on Establishing The ASEAN-China Centre between the Governments of the Member State ASEAN and China.

Banlaoi, R.C. (2003). Southeast Asian perspectives on the rise of China: Regional security after 9/11. Journal proquest.

Friedman, T.L. (2007). The world is flat, a brief history of twenty-first century. Washington: 2007.

Booth, A. (1999) Education and economic development in Southeast Asia, Myths and realities". ASEAN Economic Buletin.

Ghozali, I. (2013). Aplikasi analisis mutivariate dengan program SPSS 23. Semarang: Universitas Diponegoro.

He, L.M. (2015). 65 Tahun hubungan kontak people to people China-Indonesia. Beijing University.

Heirsh and Sharif, M. (2013) Accumulation of human capita and foreign direct investment. African Journal of Business Management.

http://asean.org/asean/asean-secretariat/history.

http://asean.org/asean/about-asean/overview/.

http://www.organisasi.org/1970/01/ international language barrier-pbb.html 


\section{EduLite}

Journal of English Education, Literature, and Culture

Volume 3, Number 1, February 2018

http://www.worldpopulationstatistics.com/.

KBRI China. (2015). 65 Tahun hubungan Indonesia-Tiongkok kemitraan untuk perdamaian dan kesejahteraan, Beijing.

Lee, C. M. (2005). China's Rise, Asia Dilemma. Proquest.

Ministry of foreign Affairs of the People's Republic of China ASEAN-China Centre. (2016). 1991-2016 (25 Years of ASEAN-China Dialogue and Cooperation: Facts and Figures).

Rauner, F. (2008). European vocational education and training. Journal of Industrial Training.

Rubini, B. (2007) Rencana strategis Departemen Pendidikan Nasional Indonesia. Bogor.

Schleicher, A. (2015). Director for education and skills education in Indonesia, rising to the challenge. OECD "Better Policies For Better Lives" ADB." $O E C D$. 